\title{
Effects of Mikania glomerata Leaf Extract on Experimental Bothropoides jararaca Envenomation in Wistar Rats
}

\author{
Yudney Pereira da Motta', Rosa Maria Barilli Nogueira', Rafael Stuani Floriano², \\ Cecilia Braga Laposy ${ }^{3}$, Annelise Carla Camplesi ${ }^{4}$, María Lucía Correal ${ }^{5}$ \& Michiko Sakate $^{6}$
}

\begin{abstract}
Background: Bothropic envenomation represents the most common ophidic accident worldwide, compared to other snakebites of medical interest. Bothropic venom has proteolytic, vasculotoxic, clotting and/or hemorrhagic actions in animals and humans. Mikania glomerata is a plant found in the Brazilian Atlantic Forest with interesting medical properties that may be useful in ameliorating the effects of ophidic venom, and thus, improving response and outcome. Although Mikania is known to act through inhibition of cytolysins in the venom, there is a lack of consistent research data. The aim of this study was to evaluate the effect of $M$. glomerata in bothropic envenomation treatment.

Materials, Methods \& Results: Clinical, hematological, biochemical, and histopathological evaluations were performed following Bothropoides jararaca experimental envenomation in three groups of 18 Wistar rats each. Group VS was inoculated in the pelvic limb via intramuscular injection of bothropic venom and received specific anti-venom serum via intraperitoneal injection. Group VSM was similarly inoculated; it received anti-venom serum and a $10 \%$ aqueous extract of the Mikania glomerata plant orally. Group $\mathrm{C}$ was the control group and received saline solution alone. Evaluations were performed at $0.5 \mathrm{~h}(\mathrm{M} 1), 6 \mathrm{~h}$ (M2), and $24 \mathrm{~h}$ (M3) after venom inoculation. Animals from both inoculated groups (VS and VSM) showed significant clinical alterations $(P<0.05)$ manifested as discomfort, uneasiness, pain, and severe edema compared to control animals. Animals from inoculated groups also exhibited statistically significant leukocytosis with neutrophilia, and elevation of blood urea nitrogen and creatine kinase until $6 \mathrm{~h}$ after inoculation $(P<0.05$ compared to control animals). An acute drop in body temperature was observed $6 \mathrm{~h}$ after inoculation $(P<0.05)$. High levels of creatinine were observed at 6 and $24 \mathrm{~h}$, and plasma protein reduction at almost all evaluation time points $(P<0.05)$ in both groups compared to that in control. Histopathological evaluation of venom-inoculated animals (groups VS and VSM) showed significant renal hydropic degeneration, acute tubular necrosis, congestion, and hemorrhage $(P<0.05$ compared to control). In contrast, animals administered plant extract in addition to anti-venom (group VSM) showed milder muscular fiber regeneration and absence of hemorrhage in the inoculated limb, compared to those that received anti-venom alone (group VS). Overall, there were no statistically significant differences between the inoculated groups $(P>0.05)$ in terms of edema reduction, pain relief, hematological, biochemical, or histopathological alterations.

Discussion: Clinical envenomation symptoms can be explained based on previous reports of bothropic events, where cytolysins such as hyaluronidase, phospholipase A2, and esterases are associated with alterations in cell membrane permeability and release of vasoactive agents. Rhabdomyolysis and muscular necrosis are the main causes of muscular and renal alterations in inoculated groups. M. glomerata extract is known to exert its inhibitory effects on vasoactive and lytic compounds responsible for muscular necrosis. However, some authors have reported only partial effectiveness of Mikania in inactivating bothropic toxins, in contrast with its greater inhibitory action on crotalic venoms. Further studies are necessary for detailed exploration of the properties of Mikania glomerata extract in order to integrate it into supportive measures for snakebite treatments in tropical and subtropical countries.
\end{abstract}

Keywords: anti-venom, bothropic, ophidic, snakebite. 


\section{INTRODUCTION}

Ophidic accidents are a problem in many parts of the world, especially in tropical and subtropical areas, with most cases caused by the Bothrops genus [1,15-17].

Bothropic venom, as a mixture of compounds, causes severe local and systemic reactions related to proteolytic, vasculotoxic, coagulant and/or hemorrhagic effects $[1,13,15]$. The above reactions are responsible for swelling, edema, necrosis, respiratory distress, disseminated intravascular coagulation, acute renal failure, and death $[4,8,12,19]$.

Anti-ophidic serum is the only validated treatment [4] for bothropic envenomation, but it needs to be accompanied by essential supportive measures such as hypovolemia correction, broad-spectrum antibiotics, tetanus prophylaxis, analgesia, and local management [1].

Serum therapy is not always accessible and its effectiveness is controversial, justifying the importance of new therapeutic strategies to reduce intensity and impact of envenomation effects [4,9]. Many plants have been used to ameliorate the effects of snakebite [1]. Among them, Mikania glomerata commonly known as "guaco," a plant found in the Brazilian Atlantic Forest, possesses multiple medical properties associated with its constituent coumarins and their derivativesterpenes, phytosterols, and flavonoids [14]. It may ameliorate the consequences of ophidic envenomation, probably through inhibition of phospholipase A2, metalloproteases, and serine proteases, which are enzymes associated with envenomation symptoms [2,9].

In this study, we aimed to evaluate effects of treatment with anti-venom or both anti-venom and aqueous extract of Mikania glomerata on experimental Bothropoides jararaca envenomation in Wistar rats.

\section{MATERIALS AND METHODS}

The experimental procedures used throughout this study were approved by the Local Ethics Committee on Animal Research.

\section{Animals and experimental groups}

Fifty-four healthy female Wistar rats (Rattus norvegicus), weighing $250 \pm 50 \mathrm{~g}$, were housed in individual stainless-steel cages and maintained under controlled conditions ( $12 \mathrm{~h}$ light/dark cycle, $24 \pm 1.0^{\circ} \mathrm{C}$, $60 \pm 5.0 \%$ humidity, and 10 cycles of air exchange, $a d$ libitum filtered water and commercial food).
Animals were divided into three experimental groups of 18 animals each. Group Venom-Serum (Group VS) received $10 \mathrm{mg} / \mathrm{kg}$ of bothropic lyophilized venom $^{1}$ via intramuscular injection in the rear left limb, and polyvalent anti-ophidic serum (Reg. No. 2817) ${ }^{2}$, as anti-venom, via intraperitoneal injection at $5 \mathrm{~mL} /$ $\mathrm{kg}, 6 \mathrm{~h}$ after venom inoculation. Group Venom-Serum and Mikania (Group VSM) received the same dose of bothropic venom and anti-venom serum, and three doses of $10 \mathrm{mg} / \mathrm{kg}$ of $M$. glomerata aqueous leaf extract (10\%, voucher specimem 16838, Botany Department IBB - UNESP, Botucatu, SP, Brazil) ${ }^{3}$ [5,9] via gavage, every $2 \mathrm{~h}$ after venom inoculation. The control group (Group C) received saline solution in place of the above treatments.

\section{Procedures}

At three different time points after venom inoculation (M1 - 0.5 h; M2 - 6 h; M3 - 24 h), animals were monitored to assess the general state, heart and respiratory rates, temperature, and edema (pachymeter) [9]. Capillary coagulation tests were also performed by using blood from the tail vein [6]. Euthanasia was practiced $24 \mathrm{~h}$ after venom inoculation by using sodium thiopental at $150 \mathrm{mg} / \mathrm{kg}$ via intraperitoneal. Intracardiac blood collection was then performed [3].

Blood constituents were assessed in an automatized CC-530 cell counter ${ }^{4}$ and differential leukocyte count were manually performed; the microhematocrit method was used to evaluate blood volume, refractometry for plasma protein level, and heat precipitation for fibrinogen level $[6,7]$. Serum was used to assess blood urea nitrogen ${ }^{5}$, creatinine ${ }^{6}$, and creatine kinase ${ }^{7}$ according to Kaneko et al. [7].

Samples from the kidneys and rear limb muscular tissues were collected for histopathological evaluation by the pathology service of the Veterinary School of UNOESTE, Presidente Prudente/SP, Brazil, according to standard procedures [18].

\section{Statistical Analysis}

ANOVA was used to establish differences between means and the Tukey test to compare parametric data. Non-parametric data were analyzed using the Kruskal-Wallis test. A $P$-value less than 0.05 ( $P$ $<0.05$ ) was considered statistically significant. All statistical analyses were carried out using the SAS/ STAT software (version 9.0)8. Data were expressed as mean $\pm \mathrm{SD}$. 


\section{RESULTS}

After venom inoculation, animals from the VS and VSM groups showed discomfort, uneasiness, pain, retraction, and intense edema of the inoculated limb. Limb edema was found to be significantly enhanced in inoculated animals than in control animals $(P<0.05)$ at all evaluation time points, the edema being considerably higher at M1 (Figure 1). A significant drop in temperature $(P<0.05)$ was noticed at M2 for the VS and VSM groups, with mean temperatures of $35.73 \pm 0.9^{\circ} \mathrm{C}$ and $34.96 \pm$ $1.26^{\circ} \mathrm{C}$, respectively, in comparison with the control group $\mathrm{C}$ with a mean temperature of $37.17 \pm 0.31^{\circ} \mathrm{C}$. There were no statistically significant differences in heart rate and respiratory rate between the VS and VSM groups $(P>0.05)$.

Lack of blood coagulability was observed in three animals at M2, two from the VS group, and one from the VSM group. Alterations in transient hematocrit, erythrocyte counts, and hemoglobin were observed in the inoculated groups, mainly at M1 $(P<0.05)$, but without clinical significance. A statistically significant increase in leukocyte counts $(P<0.05)$ was found in the VS and VSM groups at M1 and M2 than in group C (Table 1). Neutrophil counts were significantly higher $(P<0.05)$ in the VS group $\left(6.83 \pm 1.90 \times 10^{3}\right.$ cells $/ \mu \mathrm{L}$ and $6.22 \pm$ $3.67 \times 10^{3}$ cells $/ \mu \mathrm{L}$ at $\mathrm{M} 1$ and $\mathrm{M} 2$, respectively) and the VSM group $(4.95 \pm 1.57 \times 103$ cells $/ \mu \mathrm{L}$ and $12.19 \pm 4.40$ $\times 10^{3}$ cells $/ \mu \mathrm{L}$ at $\mathrm{M} 1$ and $\mathrm{M} 2$, respectively), compared to that in the control group $\left(2.29 \pm 0.55 \times 10^{3}\right.$ cells $/ \mu \mathrm{L}$ and $1.78 \pm 0.38 \times 103$ cells/ $\mu \mathrm{L}$ at M1 and M2, respectively). Lymphocyte counts were statistically significant different $(P<0.05)$ at M1 in the VS $\left(8.69 \pm 5.18 \times 10^{3}\right.$ cells $\left./ \mu \mathrm{L}\right)$ and VSM $\left(5.50 \pm 0.94 \times 10^{3}\right.$ cells $\left./ \mu \mathrm{L}\right)$ groups compared with that in the group $\mathrm{C}\left(2.56 \pm 0.49 \times 10^{3}\right.$ cells $\left./ \mu \mathrm{L}\right)$.

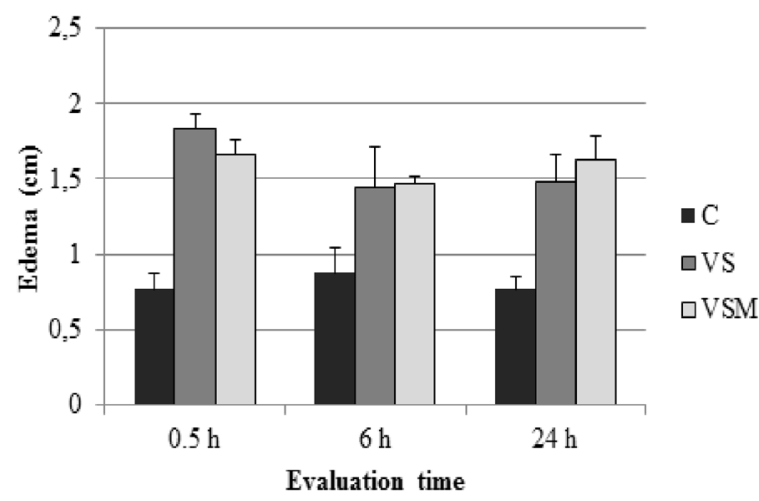

Figure 1. Left hindlimb edema measures in control and inoculated rats treated with anti-venom serum, or both anti-venom serum and Mikania glomerata extract at $0.5 \mathrm{~h}, 6 \mathrm{~h}$, and $24 \mathrm{~h}$. Data are shown as mean $\pm \mathrm{SD}$.

Table 1. Hematological parameters in control and inoculated rats treated with anti-venom serum, or both anti-venom serum and Mikania glomerata extract at $0.5 \mathrm{~h}, 6 \mathrm{~h}$, and $24 \mathrm{~h}$.

\begin{tabular}{ccccc}
\hline & $\begin{array}{c}\text { Erythrocyte count } \\
\left(10^{6} \text { cells/ } \mu \mathrm{L}\right)\end{array}$ & $\begin{array}{c}\text { Hemoglobin } \\
(\mathrm{g} / \mathrm{dL})\end{array}$ & $\begin{array}{c}\text { Hematocrit } \\
(\%)\end{array}$ & $\begin{array}{c}\text { Leukocyte count } \\
\left(10^{3} \text { cells } / \mu \mathrm{L}\right)\end{array}$ \\
\hline Group $C$ & & & & \\
\hline M1 & $8.11 \pm 0.47^{\mathrm{Ba}}$ & $14.58 \pm 0.23^{\mathrm{Ca}}$ & $43 \pm 0.01^{\mathrm{Ba}}$ & $5.64 \pm 0.88^{\mathrm{Ba}}$ \\
M2 & $6.93 \pm 0.38^{\mathrm{Ab}}$ & $13.95 \pm 0.60^{\mathrm{Aa}}$ & $42 \pm 0.01^{\mathrm{Aa}}$ & $4.24 \pm 1.99^{\mathrm{Ba}}$ \\
M3 & $6.89 \pm 0.26^{\mathrm{Ab}}$ & $14.25 \pm 0.42^{\mathrm{Aa}}$ & $42 \pm 0.00^{\mathrm{Aa}}$ & $5.20 \pm 0.95^{\mathrm{Aa}}$ \\
\hline Group VS & & & \\
\hline M1 & $9.05 \pm 0.90^{\mathrm{ABa}}$ & $16.75 \pm 0.79^{\mathrm{Ba}}$ & $49 \pm 0.01^{\mathrm{Aa}}$ & $16.60 \pm 6.75^{\mathrm{Aa}}$ \\
M2 & $6.49 \pm 0.58^{\mathrm{Bb}}$ & $13.87 \pm 1.51^{\mathrm{Ab}}$ & $41 \pm 0.05^{\mathrm{Ab}}$ & $10.75 \pm 3.32^{\mathrm{Aab}}$ \\
M3 & $5.82 \pm 0.84^{\mathrm{Ab}}$ & $11.78 \pm 1.25^{\mathrm{Bc}}$ & $36 \pm 0.03^{\mathrm{Ab}}$ & $8.47 \pm 4.26^{\mathrm{Ab}}$ \\
\hline Group VSM & & & \\
\hline M1 & $9.93 \pm 0.64^{\mathrm{Aa}}$ & $19.08 \pm 0.59^{\mathrm{Aa}}$ & $53 \pm 0.01^{\mathrm{Aa}}$ & $11.13 \pm 1.87^{\mathrm{Ab}}$ \\
M2 & $8.19 \pm 0.51^{\mathrm{Ab}}$ & $15.35 \pm 1.22^{\mathrm{Ab}}$ & $45 \pm 0.03^{\mathrm{Ab}}$ & $17.57 \pm 5.48^{\mathrm{Aa}}$ \\
M3 & $6.93 \pm 1.31^{\mathrm{Ab}}$ & $13.12 \pm 2.36^{\mathrm{ABb}}$ & $39 \pm 0.07^{\mathrm{Ab}}$ & $8.17 \pm 4.32^{\mathrm{Ab}}$ \\
\hline
\end{tabular}

$\overline{\mathrm{A}, \mathrm{B}}$ Identical uppercase letters indicate no statistically significant difference between time points $(P>0.05)$. ${ }^{\mathrm{a}, \mathrm{b}}$ Identical lowercase letters indicate no statistically significant difference between groups $(P>0.05)$. Data are shown as mean \pm SD. 
Urea nitrogen and creatine kinase levels were significantly elevated $(P<0.05)$ in inoculated groups (VS and VSM) at M1 and M2, and creatinine was elevated at M2 and M3 (Table 2), compared to those in the control group. A significant drop in protein levels $(P<0.05)$ was observed in the VS group at all evaluated time points, but interestingly, the VSM group did not show statistically significant protein reduction $(P>0.05)$ at M1. Fibrinogen did not show alterations at any evaluated time points $(P>0.05)$.
Histopathological evaluation of animals in the VSM group showed mild muscular fiber regeneration and moderate edema but no hemorrhages in the inoculated limbs, whereas animals in the VS group showed severe muscular edema and hemorrhage $(P<0.05)$. Renal hydropic degeneration, acute tubular necrosis, congestion, and hemorrhage were significantly higher in VS and VSM groups in contrast to control animals $(P<0.05)$, but there were no statistically significant differences between the different modalities of treatment $(P>0.05)$.

Table 2. Levels of urea nitrogen, creatinine, creatine kinase and plasma fibrinogen, and protein levels in control and inoculated rats treated with antivenom serum, or both anti-venom serum and Mikania glomerata extract at $0.5 \mathrm{~h}, 6 \mathrm{~h}$ and $24 \mathrm{~h}$.

\begin{tabular}{|c|c|c|c|c|c|}
\hline & $\begin{array}{l}\text { Urea nitrogen } \\
\qquad(\mathrm{mg} / \mathrm{dL})\end{array}$ & $\begin{array}{l}\text { Creatinine } \\
(\mathrm{mg} / \mathrm{dL})\end{array}$ & $\begin{array}{c}\text { Creatine Kinase } \\
(\mathrm{U} / \mathrm{L})\end{array}$ & $\begin{array}{l}\text { Fibrinogen } \\
(\mathrm{mg} / \mathrm{dL})\end{array}$ & $\begin{array}{l}\text { Protein } \\
(\mathrm{g} / \mathrm{dL})\end{array}$ \\
\hline \multicolumn{6}{|c|}{ Group C } \\
\hline M1 & $39.90 \pm 15.60^{\mathrm{Ba}}$ & $0.59 \pm 0.05^{\mathrm{Aa}}$ & $38.9 \pm 24.02^{\mathrm{Ba}}$ & $300.00 \pm 109.54^{\mathrm{Aa}}$ & $6.40 \pm 0.12^{\mathrm{Ab}}$ \\
\hline M2 & $44.90 \pm 11.72^{\mathrm{Ba}}$ & $0.57 \pm 0.04^{\mathrm{Ba}}$ & $60.5 \pm 36.65^{\mathrm{Ba}}$ & $233.33 \pm 81.65^{\mathrm{Aa}}$ & $6.10 \pm 0.27^{\mathrm{Ab}}$ \\
\hline M3 & $47.68 \pm 1.85^{\mathrm{Aa}}$ & $0.46 \pm 0.05^{\mathrm{Bb}}$ & $68.05 \pm 33.42^{\mathrm{Aa}}$ & $266.67 \pm 103.28^{\text {Aa }}$ & $6.90 \pm 0.20^{\mathrm{Aa}}$ \\
\hline \multicolumn{6}{|c|}{ Group VS } \\
\hline M1 & $50.15 \pm 8.81^{\mathrm{Ab}}$ & $0.69 \pm 0.13^{\text {Aa }}$ & $168.97 \pm 101.86^{\mathrm{Aa}}$ & $266.67 \pm 103.28^{\text {Аа }}$ & $4.93 \pm 0.30^{\mathrm{Ba}}$ \\
\hline M2 & $100.00 \pm 23.56^{\mathrm{Aa}}$ & $0.76 \pm 0.12^{\mathrm{Aa}}$ & $80.30 \pm 9.51^{\mathrm{Aab}}$ & $266.67 \pm 103.28^{\text {Аa }}$ & $4.87 \pm 0.24^{\mathrm{Ba}}$ \\
\hline M3 & $85.90 \pm 57.93^{\mathrm{Aa}}$ & $0.77 \pm 0.14^{\mathrm{Aa}}$ & $30.53 \pm 10.85^{\mathrm{Ab}}$ & $266.67 \pm 103.28^{\mathrm{Aa}}$ & $5.03 \pm 0.46^{\mathrm{Ba}}$ \\
\hline \multicolumn{6}{|c|}{ Group VSM } \\
\hline M1 & $66.41 \pm 9.1^{\mathrm{Aa}}$ & $0.71 \pm 0.07^{\mathrm{Aa}}$ & $190.00 \pm 70.89^{\mathrm{Aa}}$ & $350.00 \pm 83.66^{\mathrm{Aa}}$ & $6.3 \pm 0.45^{\mathrm{Aa}}$ \\
\hline M2 & $132.2 \pm 54.39^{\mathrm{Aa}}$ & $0.93 \pm 0.36^{\mathrm{Aa}}$ & $267.87 \pm 122.51^{\mathrm{Aa}}$ & $300.00 \pm 109.54^{\mathrm{Aa}}$ & $5.43 \pm 0.34^{\mathrm{Bb}}$ \\
\hline M3 & $98.76 \pm 88.77^{\mathrm{Aa}}$ & $0.74 \pm 0.09^{\mathrm{Aa}}$ & $25.18 \pm 17.13^{\mathrm{Ab}}$ & $300.00 \pm 109.54^{\mathrm{Aa}}$ & $5.23 \pm 0.42^{\mathrm{Bb}}$ \\
\hline
\end{tabular}

$\overline{\mathrm{A}, \mathrm{B} I d e n t i c a l ~ u p p e r c a s e ~ l e t t e r s ~ i n d i c a t e ~ n o ~ s t a t i s t i c a l l y ~ s i g n i f i c a n t ~ d i f f e r e n c e ~ b e t w e e n ~ t i m e ~ p o i n t s ~}(P>0.05)$. ${ }^{\mathrm{a}, \mathrm{b}}$ Identical lowercase letters indicate no statistically significant difference between groups $(P>0.05)$. Data are shown as mean $\pm \mathrm{SD}$.

\section{DISCUSSION}

In the present study, the venom dose at which no lethal events occurred after $24 \mathrm{~h}$ of exposure was established based on preliminary studies [5]. Envenomation symptoms were consistent with previous reports of bothropic events, in which cytolysins were responsible for most clinical symptoms, including local inflammation, edema, pain, and necrosis $[8,12,19]$. Early edema and tissue degradation occurs mainly due to proteolytic and vasculotoxic effects $[1,15]$ associated with hyaluronidase, phospholipase A2, and esterase actions, related to alterations in membrane permeability and release of vasoactive agents [4]. Coagulation disturbances are secondary to thrombin-related consequences and factor $\mathrm{X}$ activation, leading to consumption of coagulation factors as was observed in some animals in the current study $[1,17]$. Hypothermia is associated with release of histamine and bradykinin and it can be present even at $6 \mathrm{~h}$ after venom inoculation [11].

Groups inoculated with venom showed leukocytosis with neutrophilia, as was reported by others $[4,12]$. These alterations were associated with strong inflammatory reactions, stress responses, or both [12].

Increased muscular lesions in response to necrosis and rhabdomyolysis linked to phospholipase A2 action, hemorrhage, and vascular permeability alterations $[1,17]$ were associated with an increase in creatine kinase levels [15]; similarly, enhanced blood urea nitrogen and creatinine were associated with renal injury of multifactorial pathogenesis that includes nephrotoxic or ischemic mechanisms $[1,12,19]$.

Postmortem renal findings included severe congestion and hemorrhage, acute tubular necrosis, and hydropic degeneration, all of which were consistent with 
previously reported findings [4] and mechanisms of renal injury [1]. Interestingly, histopathological evaluation of animals treated with Mikania glomerata extract showed mild muscular fiber regeneration, moderate edema, and absence of hemorrhage in the inoculated limb, in contrast to the group that received anti-venom serum alone, in which muscular edema and hemorrhage were severe. These findings agree with experimentally identified anti-inflammatory and antihemorrhagic properties of the Mikania genus against myotoxic, neurotoxic, and inflammatory effects of snake venoms [2]. The above observations are further supported by the findings of other studies in rats that revealed $80 \%$ reduction in hemorrhage area following intradermal injection of Bothrops venom and Mikania extract administration [14], and reduction of inflammatory cells, edema, and hemorrhagic halo $3 \mathrm{~h}$ after administration of $B$. jararaca venom and Mikania leaf extract [10].

However, the extract of $M$. glomerata could only partially inhibit phospholipase A2 activity and edema caused by Bothrops venom, in contrast to total inhibition observed in studies using Crotalus venom, explaining the low number of beneficial effects observed in this study [9].

At the inoculated dose, bothropic venom caused sub-lethal intoxication in Wistar rats despite immediate anti-ophidic serum administration, indi- cated by alterations in hematological and biochemical parameters resulting in muscular and renal lesions.

\section{CONCLUSION}

Mikania glomerata extract at $10 \mathrm{mg} / \mathrm{kg}$ did not exhibit properties useful in management of bothropic envenomation, except amelioration of muscular edema and hemorrhage; nevertheless, it can possibly be integrated as a supportive measure to treat snakebite accidents. Further studies are necessary to determine the appropriate dose and treatment duration.

MANUFACTURERS

${ }^{1}$ CEVAP - UNESP. Botucatu, SP, Brazil.

${ }^{2}$ Laboratórios Vencofarma do Brasil Ltda. Londrina, PR, Brazil.

${ }^{3}$ Pharmacology Laboratory. Faculdades Adamantinenses Integradas. Adamantina, SP, Brazil.

${ }^{4}$ CELM - Cia. Equipadora de Laboratórios Modernos. São Paulo, SP, Brazil.

${ }^{5}$ Labtest ${ }^{\circledR}$ Diagnóstica S.A. Lagoa Santa, MG, Brazil.

${ }^{6}$ Bioclin/Quibasa Ltda. Belo Horizonte, MG, Brazil.

${ }^{7}$ Doles Reagentes. Goiânia, GO, Brazil.

${ }^{8}$ SAS Inc. Cary. NC, USA.

Ethical approval. Animal experimentation was approved (No. 036/06) by the Ethics Committee of the School of Veterinary Medicine and Animal Husbandry - UNESP. Botucatu, SP, Brazil.

Declaration of interest. The authors declare that there is no conflict of interest. The authors alone are responsible for the content and writing of the paper.

\section{REFERENCES}

1 Albuquerque P.L.M.M., Jacinto C.N., Silva Junior G.B., Lima J.B., Veras M.S. \& Daher E.F. 2013. Acute kidney injury caused by Crotalus and Bothrops snake venom: a review of epidemiology, clinical manifestations and treatment. Revista do Instituto de Medicina Tropical de São Paulo. 55(5): 295-301.

2 Collaço R.C.O., Cogo J.C., Rodrigues-Simioni L., Rocha T., Oshima-Franco Y. \& Randazzo-Moura P. 2012. Protection by Mikania laevigata (Guaco) extract against the toxicity of Philodryas olfersii snake venom. Toxicon. 60(4): 614-622.

3 Conselho Nacional de Controle de Experimentação Animal (CONCEA). 2013. Resolução Normativa 13 de 2013. Brasília: Diário Oficial da União. 11p.

4 Ferreira Júnior R.S. \& Barravieira B. 2004. Management of venomous snakebites in dogs and cats in Brazil. Journal of Venomous Animals and Toxins Including Tropical Diseases. 10(1): 112-132.

5 Floriano R.S., Nogueira R.M.B., Sakate M., Laposy C.B., Motta Y.P. \& Sangiorgio F. 2009. Effect of Mikania glomerata (Asteraceae) leaf extract combined with anti-venom serum on experimental Crotalus durissus (Squamata: Viperidae) envenomation in rats. Revista de Biologia Tropical. 57(4): 929-940.

6 Jain N.C. 1993. Essentials of Veterinary Hematology. Philadelphia: Wiley-Blackwell, 417p.

7 Kaneko J.J., Harvey J.W. \& Bruss M.L. 2008. Clinical Biochemistry of Domestic Animals. 6th edn. Burlington: Elsevier, 916p.

8 Lenchner I., Aroch I., Segev G., Kelmer E. \& Bruchim Y. 2014. A retrospective evaluation of Vipera palaestinae envenomation in 18 cats: (2006-2011). Journal of Veterinary Emergency and Critical Care. 24(4): 437-443. 
9 Maiorano V.A., Marcussi S., Daher M.A.F., Oliveira C.Z., Couto L.B., Gomes O.A., França S.C., Soares A.M. \& Pereira P.S. 2005. Antiophidian properties of the aqueous extract of Mikania glomerata. Journal of Ethnopharmacology. 102(3): 364-470.

10 Mourão V.B., Giraldi G.M., Neves L.M.G., Gaspi F.O.G., Rodrigues R.A.F., Alves A.A., Esquisatto M.A.M., Mazzi M.V., Mendonça F.A.S. \& Santos G.M.T. 2014. Anti-hemorrhagic effect of hydro-alcoholic extract of the leaves of Mikania glomerata in lesions induced by Bothrops jararaca venom in rats. Acta Cirúrgica Brasileira. 29(1): 30-37.

11 Nogueira R.M.B. \& Sakate M. 2006. Clinical and hematological alterations in dogs during experimental envenomation with Crotalus durissus terrificus venom and treated with antiophidic serum. Journal of Venomous Animals and Toxins Including Tropical Diseases. 12(2): 285-296.

12 Nogueira R.M.B. 2011. Intoxicação Por Animais Peçonhentos. In: Barilli R.M.N. \& Andrade S.F. (Eds). Manual de Toxicologia Veterinária. São Paulo: Roca, pp.295-313.

13 Ribeiro L.A. \& Jorge M.T. 1997. Acidente por serpentes do gênero Bothrops: série de 3139 casos. Revista Da Sociedade Brasileira de Medicina Tropical. 30(6): 475-480.

14 Rufatto L.C., Gower A., Schwambach J. \& Moura S. 2012. Genus Mikania: chemical composition and phytotherapeutical activity. Brazilian Journal of Pharmacognosy. 22(6): 1384-1403.

15 Sakate M., Nogueira R.M.B. \& Motta Y.P.M. 2015. Animais Peçonhentos. In: Jericó M.M., Andrade Neto J.P. \& Kogika M.M. (Eds). Tratado de Medicina Interna de Cães e Gatos. Rio de Janeiro: Roca, pp.664-677.

16 Sangiorgio F., Sakate M., Nogueira R.M.B. \& Tostes R.A. 2008. Histopathological evaluation in experimental envenomation of dogs with Crotalus durissus terrificus Venom. Journal of Venomous Animals and Toxins Including Tropical Diseases. 14(1): 82-99.

17 Sgrignolli L.R., Mendes G.E.F., Carlos C.P. \& Burdmann E.A. 2011. Acute kidney injury caused by Bothrops snake venom. Nephron - Clinical Practice. 119(2): 131-137.

18 Tolosa E.M.C., Rodrigues C.J., Behmer O.A. \& Freitas Neto A.G. 2003. Manual de Técnicas para Histologia Normal e Patológica. São Paulo: Manole, 341p.

19 Vásquez J., Alarcón J.C., Jiménez S.L., Jaramillo G.I., Gómez-Betancur I.C., Rey-Suárez P.J., Jaramillo K.M., Muñoz D.C., Marín D.M. \& Romero J.O. 2015. Main plants used in traditional medicine for the treatment of snake bites in the regions of the department of Antioquia, Colombia. Journal of Ethnopharmacology. 170(1): 158-166. 